\title{
УКРАЇНСЬКІ ДІТИ В ДІ-ПІ ТАБОРАХ ЗАХІДНОЇ НІМЕЧЧИНИ ТА АВСТРІЇ (ДРУГА ПОЛОВИНА 1940-Х - ПОЧАТОК 1950-Х РОКІВ)
}

Анотація: Діти становили близько чверті повоєнної української еміграції, котрі проживали у спеціально створених таборах для переміщених осіб і біженців на території Західної Німеччини та Австрії у другій половині 1940-х - на початку 1950-х рр. Їх дитинство проходило не лише в умовах перших складних післявоєнних років, але й у чужій краӥні в статусі дітей-біженців. У статті авторка окреслює особливості становища українських дітей у Ді-Пі таборах, їх повсякденне життя, систему виховання та дозвілля, дитячого сприйняття таборових проблем.

Ключові слова: діти, дитинство, біжениі, Ді-Пі табори, Західна Німеччина

Окремим напрямом в історіографії XX ст. стала історія дитинства. Один із засновників цього напрямку французький антрополог та історик Філіп Аp’єc (Philippe Ariès) довів, що дитинство - це не лише етап біологічного та психологічного розвитку людини, а й соціокультурний феномен, адже у різних народів або ж у різні історичні етапи існують свої характерні особливості культури дитинства ${ }^{1}$. Дитячий досвід біженства та проживання різних народів та ïх родин у таборах повоєнної Європи представлено у працях закордонних дослідників P. Балінт (Ruth Balint) ${ }^{2}$, M. Ваймана (Mark Wyman) ${ }^{3}$, T. Захри (Tara Zahra) ${ }^{4}$. Фрагментарні відомості про українських дітей у таборах для переміщених осіб і біженців Західної Німеччини та Австрії представлені у працях, що висвітлюють феномен української еміграції у повоєнний час - В. Кубійовича ${ }^{5}$, В. Маруняка ${ }^{6}$, В. Мудрого ${ }^{7}$, О. Подобєд ${ }^{8}$, К. Кобченко ${ }^{9}$. Система освіти у

\footnotetext{
* Рибачок Ірина Олександрівна - кандидатка історичних наук, старша викладачка кафедри історії імені проф. М.П. Ковальського, наукова співробітниця НДЦ «Інститут досліджень української діаспори імені професора Любомира Винара» Національного університету «Острозька академія» (Острог, Рівненська область, Україна); ORCID: https://orcid.org/0000-0001-7960-4023; email: iryna.rybachok@oa.edu.ua

${ }^{1}$ Арьес Ф. Ребенок и семейная жизнь при Старом порядке. Екатеринбург: Изд-во Урал. ун-та, 1999.

${ }^{2}$ Balint R. Children Left Behind: Family, Refugees and Immigration in Postwar Europe // History Workshop Journal. 2016. Vol. 82, Issue 1. P. 151-172.

${ }^{3}$ Wyman M. DP Europe's Displaced Persons, 1945-1951. Philadelphia; London; Toronto, 1989. 257 p.

${ }^{4}$ Zahra T. Lost Children: Displacement, Family, and Nation in Postwar Europe // Journal of Modern History. 2009. Vol. 81. №1. P. 45-86; Zahra T. The Lost Children: Reconstructing Europe’s Families after World War II. Cambridge; London, 2011. 320 p.

${ }^{5}$ Кубійович В. 3 демографічних проблем української еміграції (на прикладі таборів у Міттенвальді) // Сьогочасне й минуле. Мюнхен; Нью-Йорк, 1949. Ч. 1-2, С. 14-27.

${ }^{6}$ Маруняк В. Українська еміграція в Німеччині і Австрії по Другій світовій війні. Мюнхен: Академічне вид-во д-ра Петра Белея, 1985. Т. 1: Роки 1945-1951. 429 с.

${ }^{7}$ Мудрий В. Українська еміграція в Европі // Ювілейний календар-альманах Українського Народного Союзу на звичайний рік 1949. Джерзі Сіті, 1949. С. 107-123.

${ }^{8}$ Подобєд О.А. Культурне життя та повсякдення переміщених осіб і біженців з України у Західній Німеччині (друга половина 1940-х рр.): дис.... д. іст. н.: 07.00.01. Черкаси, 2018. 549 с.; Подобєд О. Українська планета
} 
таборах охарактеризована у статті Д. Маркусь ${ }^{10}$. Ролі жіноцтва у вихованні й опіці «маленьких Ді-Пі», а також обставинам потрапляння та соціальним категоріям дітей-біженців, присвячені статті І. Рибачок ${ }^{11}$. Отже, досвід українських дітей-біженців у Західній Німеччині та Австрії ще недостатньо вивчений в українській історіографії, оскільки лише окремі аспекти проблематики дитинства розглядалися у руслі досліджень третьої хвилі української еміграції загалом. Метою статmі є розглянути становище українських дітей-біженців у повоєнній Німеччині та Австрії, доповнити та поглибити уявлення про дитинство на «планеті Ді-Пі».

Заснування таборів, розселення втікачів і громадсько-культурне життя у них значною мірою визначалося національною ознакою. Тобто попри те, що існували інтернаціональні табори для переміщених осіб і біженців, все ж переважали табори, де більшість складала певна національна група - українці, поляки, євреї, литовці й ін. Ця ситуація була зручною як для самих політичних біженців, так і міжнародних організацій (УНPPA ${ }^{12}$ та IPO ${ }^{13}$ ), які ними опікувалися, адже вирішувало мовну проблему, запобігало етнічним конфліктам чи ворожнечі, стимулювало національно-культурне життя та перетворювало діпістів у добре організовані окремі спільноти. У свою чергу це давало можливість дітям почуватися у звичному українському родинному та громадському середовищі. Виховання «маленьких Ді-Пі» набувало важливого суспільного та політичного значення в еміграції, адже політичні втікачі, котрі не сприймали радянську Україну як самостійну українську державу, а в міжвоєнний час були розділені та проживали у різних країнах, отримали можливість самоусвідомити та прищепити українським дітям із різних регіонів, родин із різним соціальним, мовним і культурним досвідом, що вони одна нація. Втікачі мали можливість розвивати українське соціокультурне середовище та прагнули виховати «здорових фізично, чесних, з сильною волею, правдивих, христіян не на словах лише, а в ділах, освічених, допитливих і настирливих в досягненні своєї мети (але гідними шляхами), здібних підпорядковувати свої власні інтереси і навіть інтереси своєї родини загальним інтересам свого народу, своєї Держави» ${ }^{14} 3$ іншого боку обставини проживання передбачали і контакти 3 іноземцями - місцевим німецьким чи австрійським

\footnotetext{
ДіПі: культура і повсякдення. Житомир: Вид. О.О. Євенок, 2018. 396 с. Варто зауважити, що українська дослідниця О. Подобєд зосередилася також на особливостях родинного життя у таборовий період, звернула увагу на проблему сирітства. Див.: Подобєд О. Українська родина у повоєнній Німеччині: традиція і новаторство // Evropský filozofický a historický diskurz. Praha, 2016. Svazek 2.3 vydání. S. 38-45. URL: https://ephd.cz/wpcontent/uploads/2016/ephd_2016_2_3/07.pdf

${ }^{9}$ Кобченко К. Українці в епоху «Ді-Пі»: від культури повсякдення до творення (транс)національної громади // Народна творчість та етнологія. 2020. № 1 (383)

${ }^{10}$ Markus D. Education in the DP camps // The Refugee Experience: Ukrainian Displaced Persons after World War II. Edmonton: CIUS, 1992. P. 185-200.

${ }^{11}$ Рибачок I. Журнал «Громадянка» як джерело до вивчення діяльності Об’єднання українських жінок на еміграції // Наукові записки Національного університету «Острозька академія». Серія: Історичні науки. Острог, 2019. Вип. 29. С. 132-138; Рибачок I. Основні напрями діяльності Об’єднання українських жінок на еміграції (1945-1950) // Наукові записки Національного університету «Острозька академія». Історичні науки. Острог, 2019. Вип. 28. С. 47-55; Рибачок I. Українські діти-біженці у Західній Німеччині після Другої світової війни: шляхи потрапляння та соціальні категорії // Наукові записки Національного університету «Острозька академія». Серія «Історичні науки». Острог, 2020. Вип. 31. С. 86-96.

${ }^{12}$ уНРРА (Адміністрація Організації Обєєднаних Націй для допомоги і відбудови, англ. - United Nations Relief and Rehabilitation Administration (UNRRA).

${ }^{13}$ IPO (Міжнародна організація у справах біженців, англ. - International Refugee Organization (IR0).

${ }^{14}$ Доктор Дражевська. Бережіть дитячу душу // Громадянка. 1946. № 1. С. 10.
} 
населенням, американськими, французькими, британськими представниками військових адміністрацій і працівниками міжнародних організацій. Дітей особливо вражали речі, норми поведінки чи елементи іншої культури, які вони зустрічали вперше. Певні звички, елементи поведінки чи навіть мову вони швидко переймали в іноетнічному середовищі ${ }^{15}$.

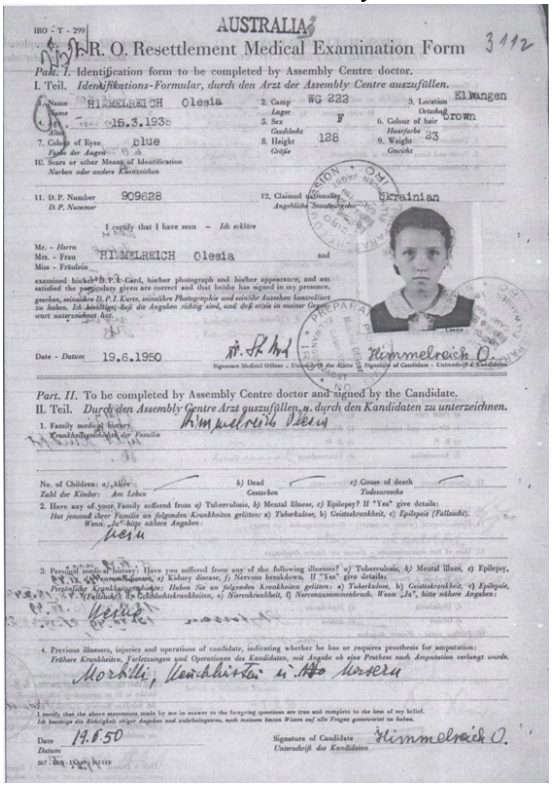

Рис. 1. Документ про проходження медичної комісії (ЦДАЗУ. Ф. 72. Оп. 1. Спр. 2. Арк. 6зв.)
Діти, як і дорослі, отримували статус Ді-Пі та посвідчення біженця 3 конкретним чисельним номером. Цей номер зазначався на усіх дитячих документах, що стосувалися різних процедур, які були пов'язані із проживанням у таборі, проходженні медичних комісій, довідок, документів на переселення, квитків (рис. 1). Народжені у таборовий період діти отримували свідоцтво про народження. Статус дітей-біженців надавав можливість бути під опікою суспільної служби УНРРА, яка здійснювала патронаж над «маленькими Ді-Пі», забезпечувала харчовими пайками, одягом, слідкувала за умовами проживання, адаптації та повоєнної реабілітації дітей-війни. Діти могли отримати «статус Ді-Пі» і можливість проживати у таборах для біженців навіть після 1947 р., тобто після того, як «новим» дорослим цього статусу вже не надавали.

Українці дотримувалися традиції хрещення новонароджених і залежно від віросповідання батьків, її хрестив священник відповідної таборової церкви. Під час хрещення також видавали документ про здійснення таїнства. Хрещеними батьками ставали знайомі, котрі, як правило, проживали в одному таборі. Навіть попри складні матеріальні та побутові обставини українці намагалися хоч скромно та все ж відзначити важливу родинну подію у колі найближчих людей.

Діти проживали разом із своїми родинами у таборових кімнатах. Житлові умови були незадовільними ${ }^{16}$, особливо для проживання малих дітей (відсутність долівки, проблеми 3 дахом, вибиті шибки, відсутність системи опалення, меблів, переповненість таборових кімнат). Повсякденне життя дітей у таборах для біженців визначалося тими складнощами, що були характерні для усієї української післявоєнної еміграції. Вони були пов'язані, у першу чергу, з недостатнім забезпеченням базових потреб: нестача їжі, одягу, взуття, відсутність дому, складні побутові умови у таборах, часті переїзди, хвороби, проблеми переселення. Як і для дорослих, для дітей надавалися харчові картки та встановлювалися норми харчування. Малеча харчувалася на спеціально створених дитячих кухнях, або ж приватно ${ }^{17}$. Дитячі кухні забезпечували додатковим харчуванням дошкільнят, школярів і студентів.

\footnotetext{
${ }^{15}$ Українка на чужині. Таборовий часопис Об’єднання українських жінок. Делегатура Діллінген. 1948. Ч. 1. C. 4.

${ }^{16}$ Більшість таборів для біженців розташовувалася на території і в приміщеннях колишній німецьких казарень, старих заводах, фабрик. Якщо в Західній Німеччині більшість цих таборів розміщувалася у мурованих приміщеннях, то в Австрії - у дерев'яних.

${ }^{17}$ Родина готувала та споживала їжу безпосередньо у таборовій кімнаті, а не в таборовій кухні.
} 
Відповідно до цього, та залежно від вікової категорії, у Ді-Пі таборах встановлювалися норми тижневої видачі дитячих харчів. У таборі Міттенвальд, діти віком від шести до сімнадцяти років, котрі не харчувалися у таборовій кухні отримували на тиждень по 2450 г. хліба, 300 г. муки, 350 г. сухого молока, 175 г. свіжого масла, 140 г. цукерок, 140 г. солі, 50 г. кави, 70 г. яєчного порошку, 100 г. зупи, 105 г. шоколаду, 525 г. соку, 6 унцій вершків, 350 г. зупи, 420 г. м’яса і 3150 г. картоплі, 3 шт. вітамін ${ }^{18}$. Натомість «маленькі Ді-Пі», що відвідували таборову кухню, додатково отримували 810 г. хліба, 100 г. сухого молока, 135 г. свіжого масла, 140 г. цукерків, 35 г. яєчного порошку, 105 г. шоколаду, 525 г. соку, 70 г. зупи і 3 вітамін ${ }^{19}$. Малята від народження до п'яти років розподілялися на три групи відповідно до харчового пайка: 1) від народження до шести місяців життя отримували 175 г. крохмалю, 175 г. пудингу, 420 г. цукру, 3 шт. вітамін; 2) від шести місяців до року - той же набір, що й попередня категорія, а також 100 г. свіжого масла, 700 г. соку; 3) від одного до п'яти років одержували 70 г. свіжого масла, 125 г. цукру, 105 г. шоколаду, 700 г. соку і 3 шт. вітамін ${ }^{20}$.

У деяких таборах, згідно розпоряджень таборової адміністрації, визначалося, що шкільна додаткова їжа не може видаватися у сухому вигляді (пайок), а їі необхідно видавати у вигляді готових страв ${ }^{21}$. Цікаво, що у дитячий пайок входили продукти, які діти не споживали, наприклад кава. Ці продукти батьки вимінювали на свіжі сільськогосподарські продукти харчування у німецьких фермерів, яких для відживлення та збалансованого харчування малечі бракувало свіжі яйця, молоко, масло, овочі. Деякі таборяни сіяли городину на таборових городах, зважаючи на тотальний дефіцит овочів. Іноді через дитячі пустощі страждала господарка таборян, а їх батькам у зв'язку з цим навіть погрожували виселенням. Йдеться про скарги на дітей, оскільки ті зривали квіти, недоспілі овочі та нищили городину, зриваючи квіти помідорів, гороху тощо 22 . Цікаво, що іноді практика утримання городу існувала навіть у таборових дитячих садках, де кожна дитина мала свою грядку ${ }^{23}$.

Дослідниџя О. Подобєд відзначає, що рівень харчування дорослих таборян, попри його одноманітність, був все ж кращим ніж у німецького населення і становив 2-2,5 тис. калорій на день $^{24}$. Кількість денних калорій для малят віком до одного року становила від 1151 калорій. Для того, щоб збільшити добову кількість калорій для дітей і сприяти кращому відживленню українські діаспорні допомогові та жіночі організації ${ }^{25}$ надсилали для дітей-біженців від 0 до 14 років додаткові харчі. Дитина на місяць могла отримати один англійський фунт смальцю (близько 450 г.), 1/2 фунта цукру (близько 225 г.), 200 г. трану (рибяяого жиру), сухе молоко, яєчний порошок ${ }^{26}$. Особливою радістю для дітей-біженців були саме пакунки «Сare», які час-

\footnotetext{
${ }^{18}$ Що, коли, кому і де дають // Таборові будні. Міттенвальд, 1947. №1. С. 8.

${ }^{19}$ Ibidem.

${ }^{20}$ Ibidem.

${ }^{21}$ Наказ по ганноверському табору ім. Лисенка 38 лютого 1947 р. // Бюлетень табору імені Лисенка. 1947.

Ч. 431, неділя 9 лютого. С. 3.

${ }_{22}^{22}$ Оголошення. До батьків // Вісник Оселі. Регенсбург. Р. І. Ч. 20.24 червня 1947. С. 2-3.

${ }^{23}$ Один рік в таборі Ельванген 1946-1947. Ельванген, 1947. С. 25.

${ }^{24}$ Подобєд О.А. Культурне життя та повсякдення переміщених осіб і біженців з України... С. 299.

${ }^{25}$ Зокрема, Злучений Український Американський Допомоговий комітет, Українські допомогові комітети, Союз українок Америки, Комітет українок Канади й ін.

${ }^{26}$ Архів УВУ. Папка «ОУЖ». Список дітей в Франкфурті на Майні. Допомога діти дітям з Америки [рукопис]; Архів УВУ. Папка «ОУЖ». Список дітей від 0-14 років життя. Приділ по 200 г. трану [рукопис].
} 
то видавали на свята, у них крім консервів з шинкою SPEM, сухого молока, какао, кексів, були ще й шоколадки та цукерки «Life Savers» ${ }^{27}$. Допомогові збірки у середовищі української діаспори США та Канади для українських дітей-біженців, котрі перебували в повоєнній Західній Німеччині та Австрії, відбувалися під гаслом «Діти - дітям», оскільки до цих акцій активно залучали також маленьких американських українців.

У дітей відчувалася нестача одягу, взуття, візочків, дитячих ліжечок та інших дитячих речей. Міжнародні та українські допомогові організації надавали вживані дитячі речі - шкарпетки, черевики, блюзи, сорочки, сукенки, светри або окремі шматки тканини ${ }^{28}$. Вони розподілялися пропорційно відповідно до чисельності мешканців окремих таборових блоків, проте необхідних речей не завжди вистачало на усіх. Представниці/ки українських жіночих організацій і санітарно-харитативних відділів ЦПУЕН ${ }^{29}$ укладали спеціальні списки найбілыш потребуючих, а у випадку видачі речей фіксували інформацію про кожну дитину (ії прізвище, ім'я, рік народження й одержаний одяг під підпис). Ці списки дають чітке уявлення про те, що вистачало для всіх лише шкарпеток, весь інший одяг і його кількість надана кожній конкретній дитині різнилася ${ }^{30}$. Ще складнішою була ситуація із дитячим взуття, яке швидко зношувалося.

Забезпечення родини одягом частіше лягало на плечі жінок, тому досить швидко українські жіночі організації в Німеччині та Австрії почали відкривати кравецькі майстерні, які шили у т.ч. дитячий одяг. Жінок вчили шиттю на спеціальних кравецьких курсах, які організовувало ОУЖ31. Матері самостійно шили, ремонтували, перешивали чи в'язали щоденне вбрання та готували костюми для дитячих виступів під час різних імпрез. Шматки тканини, нитки для вишивання, машинки для шиття отримували від українських допомогових і жіночих організацій. Оскільки й цього не вистачало, використовували старі речі, військову форму чи знайдений парашутний матеріал, з ковдр шили теплий одяг.

Леся Богуславець ${ }^{32}$, дочка письменника Дмитра Нитченка, що навчалася в таборовій гімназії згадувала, що «...суконки не було, ходила в перешитих мамою військових штанях» ${ }^{33}$. До речі, пластові однострої також виготовляли з перефарбованої у темний колір американської військової форми ${ }^{34}$. Старші діти могли ділити одяг з батьками. На тогочасних фото діти зображені у повсякденному, офіційному та святковому одязі. Так, останній був представлений вишиванками, або ж святковими костюмами з нагоди свят.

Популярністю користувалися вишиті речі: сорочки, кожушки. Вишиті речі були справжньою розкішшю і одягалися лише на свято чи дитячі виступи. Частина вишиванок була вивезена під час втечі, а частина - вишита вже у таборах. Ниток для вишивання не вистачало, тому жінки використовували різнокольорові прапорці, з яких витягували нитки, мочили в

\footnotetext{
${ }_{27}^{27}$ Залеська Онишкевич Л. Бомби, границі і два праві черевички. Друга світова війна очима дитини-біженця. Львів: Літопис, 2018. С. 174.

${ }^{28}$ Архів УВУ. Папка «ОУЖ». Список дітей в Франкфурті на Майні. Допомога діти дітям з Америки [рукопис].

${ }^{29}$ Центральне представництво української еміграції в Німеччині.

${ }^{30}$ Архів УВУ. Папка «ОУЖ». Список дітей в Франкфурті на Майні. Допомога діти дітям з Америки [рукопис].

${ }^{31}$ ОУЖ - Об'єднання українських жінок на еміграції (в Німеччині).

${ }^{32}$ Справжнє ім'я - Олександра Ткач.

${ }^{33}$ Богуславець Л. Судженого й конем не обї̈деш. Київ, 2016. С. 248.

${ }^{34}$ Палієнко-Павлюс П. Про пласт і наше таборування (спомини) // Незабутні роки 1945-1950. Памяткове видання. Нью-Йорк; Чікаго, 1987. С. 136.
} 
оцті, щоб не облізали і ними вишивали ${ }^{35}$. Вишивання залишалося традиційним, поширеним і дуже популярним промислом у таборовий період. У тогочасній жіночій пресі друкували викройки, зразки дитячого одягу, узори для вишивання. Офіційний дитячий одяг часто виглядав як менша копія дорослого вбрання.

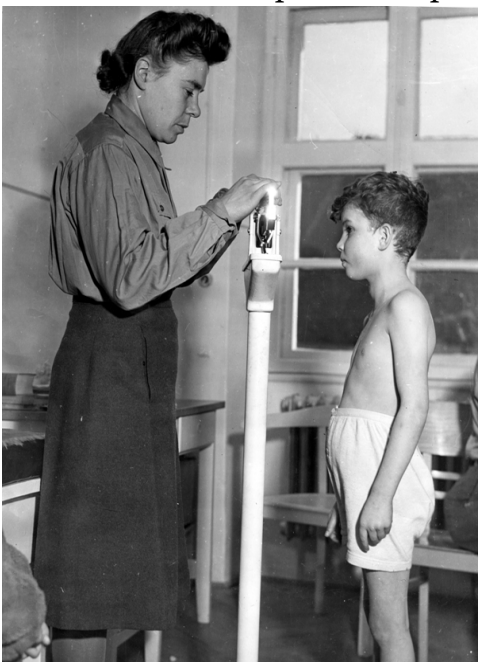

Рис. 2. Зважування дітей-біженців у таборі

Недоїдання, незбалансоване харчування, фізичні та психологічні травми, отриманні під час війни чи втечі, умови проживання негативно впливали на дитяче здоров'я. Частою проблемою була недостатня для свого віку вага, нестача вітамінів, втрата свідомості. Суспільна служба УНPРА ввела процедуру систематичного зважування дітейбіженців для контролю ваги (рис. 2). У таборах процедуру проводив дитячий лікар. Так, у таборі Ельванген зважували дітей один раз на тиждень і профілактично видавали «Vigantol» ${ }^{36}$. Попри це малеча мала проблеми зі здоров'ям, у т.ч. і кісток ${ }^{37}$. Діти хворіли на різноманітні інфекційні та вірусні хвороби (застуди, запалення горла та легенів, кір, паротит $)^{38}$. Відсутність ліків або невчасна медична допомога могла призводити й до дитячої смертності через такі хвороби як запалення горла ${ }^{39}$. у таборах, де жило велике скупчення людей, медичні служби проводили профілактичні заходи 3 метою запобіганню інфекційним хворобам: дезінфекцію людей і приміщень порошком Ддт ${ }^{40}$, вакцинацію дітей від віспи, дифтерії, коклюшу, плямистого тифу й ін. ${ }^{41}$

Спостереження за станом здоров'я «маленьких Ді-Пі» здійснював дитячий лікар, дитяча медсестра та дантист. Медична служба таборів проводила систематичні дитячі огляди. У випадку, якщо хтось ухилявся їх регулярно проходити, то родину позбавляли харчових карток. Лікування складних захворювань або хірургічні операції відбувалися у німецьких чи австрійських лікарнях поза табором. Нескладними та поширеними операціями було видалення

\footnotetext{
${ }^{35}$ Архів НДЦ «Інститут досліджень української діаспори імені професора Любомира Винара» Національного університету «Острозька академія». Папка «Ляриса Музичка». Стефанія Зварун. Колисав ії колиску вітер рідного Поділля (за Б. Лепким)». Арк. 4.

${ }^{36}$ Препарат, який регулює обмін кальцію та фосфору, запобігає розвитку рахіту та проблем із формуванням кісток. Див.: Д-р. Т-ук. Шпитальництво й медична допомога в таборі Ельванген // Один рік в таборі Ельванген 1946-1947. Ельванген, 1947. С. 15.

${ }^{37}$ Наталія Кононенко: «Фольклор - це спосіб осмислення травматичного досвіду, перетворення жахів в мистецтво» [iнтерв'ю з Устиною Стефанчук] // Україна модерна. Міжнародний інтелектуальний часопис. URL: https://uamoderna.com/jittepis-istory/natalka-kononenko

${ }^{38}$ Стецьків Е. Медична опіка в Міттенвальді // Міттенвальд 1946-1951 / Ред.ком. П. Рогатинський, О. Бучацький, О. Дужий та ін. Warren, Michigan, 2001. С. 91; Кузьма М. Я також був в Міттенвальді // Міттенвальд 1946-1951 / Ред.ком. П. Рогатинський, О. Бучацький, О. Дужий та ін. Warren, Michigan, 2001. С. 100.

${ }^{39}$ Бризгун-Соколик О. Регенсбург табір ДіПі 1945-1949 «Україна в мініятюрі» (Спомини) // Наукові записки Національного університету «Острозька академія». Серія «Історичні науки». 2020. Вип. 31. С. 249.

${ }^{40}$ Дихлорфеніл трихлорметилметан (дуст). Див.: Міттенвальд 1946-1951 / Ред.ком. П. Рогатинський, О. Бучацький, О. Дужий та ін. Warren, Michigan, 2001. С. 11.

${ }^{41}$ Міттенвальд 1946-1951... С. 10, 38.
} 
аденоїдів, яке проводилося без анестезії. Після такої процедури дитині давали морозиво, булочку-кайзерівку та помаранчу, які в уяві тогочасних українських дітей-біженців були справжньою розкішшю ${ }^{42}$. Натомість важким психологічним бар'єром було те, що операції робили німецькі лікарі, а діти не розуміли їх мови, цей досвід для частини малих пацієнтів був досить травматичним: «вони на мене кричали, я плакала...» ${ }^{43}$.

Серед української дітвори у таборах і поза ними відбувалося зростання захворюваності на туберкульоз, яке становило близько 40\% від загальної кількості випадків ${ }^{44}$. Так, у 1948 р. на території британської зони зафіксовано 202 дитини хворі на туберкульоз ${ }^{45}$, найбільше у таборах Вайне (39), Фалькенберг (26), Лінторф (20), Ганновер (15) ${ }^{46}$. У залежності від стану маленьких пацієнтів тривале лікування відбувалося в таборових шпиталях, німецьких чи австрійських лікарнях і спеціальних санаторіях. Протитуберкульозні санаторії для дітей існували у Кемптені (Баварія, американська зона), Бад Ребургу (Нижня Саксонія, британська зона) ${ }^{47}$, які знаходилися у гірській місцевості.

Тривале лікування у санаторіях в іноетнічному й іншомовному середовищі призводило до того, що діти забували українську мову і розмовляли «чужою». У 1947 р. у санаторії Бад Ребург лікувалося 36 українських дітей, які зовсім забули мову ${ }^{48} .3$ метою підтримки та спілкування рідною мовою їх відвідували представники/ці українських жіночих і допомогових організацій (ОУЖ, СХС), українські священники.

Поширенню туберкульозу сприяло погане харчування та велике скупчення людей у таборах (у т.ч. хворих відкритою формою туберкульозу). Наслідком цього захворювання могла бути і смерть. У своїх споминах Ірина Ганушевська-Руснак описує як саме за таких обставин втратила єдину доньку. Ї̈̈ 16-місячна Христинка захворіла на туберкульоз, оскільки разом із ними в кімнаті проживав чоловік, що страждав на відкриту форму цього захворювання ${ }^{49}$. Лікарі не змогли врятувати дівчинку і родина поховала її у могилі померлої подруги сімї̈, оскільки після війни у Західній Німеччині не дозволяли хоронити малих дітей в окремих могилах довше ніж на п'ять років, бо після цього терміну прах дитини переносили до спільної могили ${ }^{50}$. Через різні хвороби помирали не лише маленькі діти, але й старші, яким довелося пережити жахи війни. У 1946 р. 6-річний Роман Воронка, втратив свого старшого брата, котрий помер від менінгіту. Попри те, що мати постійно сплачувала кошти для власника цвинтаря навіть після виїзду до Канади, могила хлопчика не збереглася ${ }^{51}$. Як зазначає у споминах

\footnotetext{
${ }^{42}$ Залеська Онишкевич Л. Бомби, границі і два праві черевички... С. 144.

${ }^{43}$ Легка-Герець А. Мій рід і моє дитинство // Герець М. У світ широкий з Україною в серці. Київ: Смолоскип, 2018. С. 390.

${ }^{44}$ Мудрий В. Українська еміграція в Европі // Ювілейний календар-альманах Українського Народного Союзу на звичайний рік 1949. Джерзі Сіті, 1949. С. 111.

${ }^{45}$ Звіт $з$ діяльності Крайового Представництва Української Санітарно-Харитативної Служби на бритійську зону Німеччини за 1948. С. 9.

${ }^{46}$ Ibidem.

47 Звідомлення Злученого Українського Американського Допомогового комітету. 3 діяльности в Західній Европі за 1948 рік. Мюнхен, 1949. С. 39; Звіт з діяльності Крайового Представництва Української СанітарноХаритативної Служби на бритійську зону Німеччини за 1948. С. 9.

${ }^{48}$ Хроніка. Хворі діти.15.03.48 // СХС. Бюлетень. Інформації. Ганновер, 1948. Ч. 1. С. 11.

${ }^{49}$ Ганушевська-Руснак I. Спомини. Івано-Франківськ: Місто НВ, 2009. С. 42.

${ }^{50}$ Ibid. C. $42-43$.

${ }^{51}$ Воронка Р. Дитинство на плянеті «Ді-Пі» // Альманах УНС. Парсиппані, Нью-Джерсі: Видавництво «Свобода», 2008. С. 139.
} 
Л. Залеська Онишкевич, крім болю від втрати рідних втікачі, котрі розуміли тимчасову присутність у місці втрати, відчували ще й страх і почуття вини, що залишають могилу в чужому краю, без надії колись її відвідати ${ }^{52}$.

Загальні статистичні відомості щодо кількості смертельних випадків у таборах для біженців у Німеччині та Австрії відсутні. В. Кубійович стверджував, що серед української еміграції в післявоєнний час була низька смертність, у т.ч. дитяча ${ }^{53}$. Таборовий лікар Іван Базилевич зазначав, що дитяча смертність виросла навесні 1947 р., пояснюючи це тим, що значна частина батьків боялася віддавали малят до шпиталів і зверталася за медичною допомогою занадто пізно ${ }^{54}$. У споминах таборян фіксуються випадки дитячої смертності, можливо зважаючи на те, що це призводило до шоку і болю не лише родичів, а й інших таборових мешканців.

Під час війни діти не мали змоги систематично відвідувати школу, пропустили кілька років навчання або ж мали складнощі під час навчання у місцевій німецькій чи австрійській школі. У зв'язку з поверненням до мирного життя, однією з нагальних проблем була організація системи освітніх закладів для дітей у таборах: дитячих садочків, шкіл, гімназій, курсів і позашкільної освіти. Зауважимо, що національні школи у таборах мали представники багатьох народів, що були біженцями. Власна система освіти мала важливе значення для морального та національного виховання, збереження національних освітніх традицій та виховання національної свідомості у дітей-біженців. Такі школи вирішували мовне питання, адже кожна дитина-біженець могла навчатися рідною мовою.

Водночас, дослідники відзначають, що таборова освіта мала низку проблем: 1) відсутність комфортних належних для навчання умов (приміщень ${ }^{55}$, меблів, шум у коридорах, відсутність системи опалення тощо); 2) відсутність навчальних та методичних матеріалів, підручників, паперу, канцелярського приладдя ${ }^{56}$. Діти писали на залишках обгорткового паперу ${ }^{57}$.

Становище українців не було винятковим, подібні труднощі переживали й інші. Так, одного разу литовські діти у таборі Шейнфельд отримали гуманітарну допомогу у вигляді великого запасу зошитів, уже заповнених написами американських учнів. Не маючи гумок, литовські учні намагалися стирати, натираючи хлібом, а потім нарешті здалися і просто написали поверх речень американців ${ }^{58}$. До кінця 1940-х рр. ситуація із забезпеченням шкільним приладдям і підручниками покращилася, з'явилися підручники для українських школярів («Школярик» (посібник для народних шкіл для 2 класу); «Школяр» (посібник для народних шкіл для 3-4 класу) ${ }^{59}$ ).

Важлива роль в організації та функціонуванні дошкільної, шкільної, позашкільної,

\footnotetext{
52 Залеська Онишкевич Л. Бомби, границі і два праві черевички... С. 132.

${ }^{53}$ Кубійович В. 3 демографічних проблем української еміграції (на прикладі таборів у Міттенвальді) // Сьогочасне й минуле. Мюнхен; Нью-Йорк. 1949. Ч. 1-2. С. 25.

${ }^{54}$ Базилевич I. Спостереження таборового лікаря // Сьогочасне й минуле. Мюнхен; Нью-Йорк. 1949. Ч. 1-2.

C. 27-31.

${ }_{55}^{55}$ Приміщеннями для шкіл часто виступали гаражі, що мали цементну підлогу.

${ }^{56}$ Подобєд О.А. Культурне життя та повсякдення переміщених осіб і біженців з України... С. 116.

${ }^{57}$ Залеська Онишкевич Л. Бомби, границі і два праві черевички... С. 154.

${ }^{58}$ Wyman M. DP Europe's Displaced Persons, 1945-1951... P. 100.

${ }^{59}$ Слово. Регенсбург, 1946. Ч. 12 (19). С. 6.
} 
спеціальної освіти належала педагогічному колективу. На еміграції опинилася значна кількість викладачів, професорів. Згідно досліджень Д. Маркусь влітку 1948 р. у трьох зонах Німеччини опинилося 1103 вчителів і 259 університетських професорів ${ }^{60}$. Як зазначає дослідниця, саме вчителі вчили дітей з різних регіонів України, що входили напередодні війни до різних держав, що вони - одна нація, один народ ${ }^{61}$. Безперечно, це впливало на формування й усвідомлення ідентичності цих дітей поза Україною як українців. У споминах осіб, що дітьми опинилися у таборах для біженців, вчителі згадуються з особливою теплотою та вдячністю: «...вони зуміли нам не тільки причепити знання, але і надігнати те все, що ми стратили через війну» 62 .

Крім того, значна кількість видатних діячів, митців, котрі працювали у таборових закладах освіти чи просто проживали в таборах, мали колосальний вплив на формування світогляду дітей, ïx зацікавлень, а не лише на засвоєння знань з окремих предметів. Крім того, «близьке сусідство» у таборі створювало умови легкого доступу та можливості спілкування дітей з українськими письменниками, митцями та громадськими діячами, котрі своєю поведінкою, вчинками, творчістю, розмовами у неформальних обставинах ставали певним зразком українського інтелігента, прикладом для наслідування.

Наявність у таборах маленьких дітей викликала необхідність створювати дитячі садочки, де вони могли розвиватися та перебувати поза таборовою кімнатою. Значну роль у заснуванні дитячих садочків у таборах відіграло жіноцтво. Відома громадська діячка, одна з організаторок дитячих садочків, членкиня ОУЖ, редакторка дитячих видань Лідія Гаєвська так охарактеризувала становище та психічний розвиток маленьких мешканців таборів і у зв'язку 3 цим визначила головні завдання дитячих садків: «Діти стали метушливими, вони втратили здатність зосереджуватися, спокійно заглиблюватися у якусь працю, у них виробилася звичка кудись поспішати. Діти відвикли говорити тихо. Спільне життя у кімнатах по 6-8 чоловік, а інколи і по 20, призвело до того, що діти тільки кричать. Раніше діти приходили у садок, щоб побути у громаді, гурті, а тепер діти бувають у гурті цілий день. Тому важливим завданням є створити умови в таборових садках, щоб вони стали місцем тихого відпочинку, як у хаті ${ }^{63}$.

Один із кращих дошкільних закладів був у Ельвангені, він мав добре забезпечення та колектив вихователів. Садочок очолювала Лідія Гаєвська і на його базі ОУЖ організовувала курси для виховательок ${ }^{64}$. Вихователі творчо підходили до своєї роботи, організовували свята, дитячи імпрези, писали сценарії та готували дітей до виступів під час різноманітних свят Св. Миколая, Різдва Христового, Шевченківських свят, дня матері, весни, дитячих фестивалів та ярмарків. У організації цих свят допомагали культурно-освітній відділ ЦПУЕН і культурноосвітня референтура ОУЖ. Вони готували сценарії для дитячих свят і надсилали до різних таборових українських садочків ${ }^{65}$. Ці свята були надзвичайними подіями у житті таборової

\footnotetext{
${ }^{60}$ Lalande J. «Building a Home Abroad» - A Comparative Study of Ukrainian Migration, Immigration Policy and Diaspora Formation in Canada and Germany after the Second World War. Toronto, 2006. P. 70; Markus D. Education in the DP camps... P. 194.

${ }^{61}$ Markus D. Education in the DP camps... P. 191.

${ }^{62}$ Палідвор-Зєлик Л. Тисяча доріг - тисяча стежин. Спомини. Нью-Йорк, 2020. С. 36.

${ }^{63}$ Гаєвська Л. Бережім дітей // Громадянка. 1948. Ч. 7-8. С. 6.

${ }^{64}$ Громадянка. 1946. Ч. 1. С. 25.

${ }^{65}$ Праця українських жінок у Регенсбурзі Оселі й Області // Вісник Оселі. Регенсбург. 1947. Р. І. Ч. 34 (14 жовтня). С. 1.
} 
дітвори. Під час виступів діти отримували подарунки та заохочення, а глядачі - моральне задоволення та піднесення. Так, у грудні 1945 р. в таборі Інгольштадт на миколаївські свята діти отримали по дві шоколадки, доморобні помадки, цератових ${ }^{66}$ звірят або дерев'яні іграшки, що були виготовлені у таборовій майстерні дитячих забавок ${ }^{67}$. Такі дитячі виступи проходили перед батьками, адміністрацією та мешканцями табору, а іноді представниками міжнародних організацій. Ці вистави слугували способом психотерапії як для дітей, які були зайняті підготовкою до свят і менше зважали на життєві складнощі, так і для дорослих.

Дітей залучали до повсякденних суспільних таборових практик. У таборі Інгольштадт була щоденна традиція, коли ввечері мешканці сходилися до таборової площі, жінки з чоловіками ставали в різні сторони, а посередині - діти, які читали вголос молитву, а батьки за ними повторювали. Це створювало неймовірну атмосферу і для багатьох було найкращим моментом таборового дня ${ }^{68}$. Молитва - була важливою не лише зважаючи на релігійність українського народу, а й тому, що у складних таборових умовах саме вона була засобом боротьби 3 травматичним досвідом у зв'язку з пережитим минулим і складним, невизначеним життям біженців. Зі спільної молитви починався день навіть у таборовому садочку ${ }^{69}$. Так, в Людвігсфельді біля Мюнхену ранок починався молитвою дітвори, яка закінчувалася словами:

«Бозю, дай здоровля мамі, татові

І всій родині, а долю, волю

Верни рідній Україні» ${ }^{70}$.

Важливу роль у процесі виховання та формування світогляду українських дітейбіженців відігравала преса та книжкові видання. Для наймолодших у таборі в Ельвангені видавали дитячу газету «Сонечко» (1947, ред. Л. Гаєвська), книгу «Любі малята» (авт. Л. Гаєвська, 1947, 16 с.). У Мюнхені виходив дитячий журнал «Вовченята» (Мюнхен; Фрайман, 1946). Для найменших школярів у Реґенсбурзі видавали «Малий школяр на чужині» (1948, ред. Ю. Бескид). у дитячих виданнях містився різноманітний розвиваючий матеріал для найменших мешканців таборів: вірші, скоромовки, дитячі оповідання, завдання на розвиток логіки, уважності, навіть розмальовки. Важливо, що це були україномовні матеріали, а їх значна частина розкривала у відповідній формі інформацію про Україну, її регіони, пояснювались причини перебування поза Батьківщиною. Їх могли використовувати вихователі садочку та батьки. Попри те, що якість друку, папір і тираж цих видань були досить скромними, у таборових умовах це було великим досягненням.

Для дітей шкільного віку організовувалися початкові школи (4 класи) та гімназії (8 класів). Іноді діти у зв'язку з навчанням були розділені з батьками. Траплялося, що члени однієї родини жили у різних таборах чи батьки жили приватно, а дитина навчалася у таборовій школі. Навіть попри це старші діти, котрі пам'ятають свій таборовий досвід навчання, згадують його як щасливий період життя, адже закінчилася війна. Вони жили у великих кімнатах на десять-шістнадџять осіб і називали їх гуртожитки. Леся Богуславець згадує про своє життя у такому гуртожитку: «У таборі Карлсфельд прожила один щасливий рік. Жила в гуртожитку,

\footnotetext{
${ }^{66}$ Церата - тканина, на одну або обидві сторони якої нанесено водонепроникне покриття.

${ }^{67}$ Софронів Левицький В. Республіка за дротами (записки скитальця). Торонто: Вид-во «Новий шлях», 1983. С. 41.

${ }^{68}$ Ibid. C. 19.

${ }^{69}$ Один рік в таборі Ельванген 1946-1947. Ельванген, 1947. С. 25.

${ }^{70}$ Вісті $з$ фонду «Мати і дитина» // Наше життя. 1955. Лютий. С. 33.
} 
за нами доглядала восьмикласнищя. ...Незважаючи на голод і холод, але тут я могла ходити в школу навколо була молодь, мала друзів» ${ }^{71}$. Такі обставини змушували шукати друзів, які в умовах відсутності родичів ставали близькими людьми, підтримкою ${ }^{72}$. Однак, нестабільність, невизначеність, реорганізація та закриття таборів змушували часто змінювати табори і школи, а відповідно, втрачати друзів. Протягом 1945-1948 рр. Леся Богуславець навчалася в гімназіях у Карсфельді, Старому Ульмі, Новому Ульмі, Етлінгені ${ }^{73}$. Та все ж пережиті в юності складнощі та радощі на чужині зміцнювали дружбу, яка тривала між колишніми однокласниками, що згодом опинилися на різних континентах, у різних країнах чи містах. Л. Палідвор-Зєлик, що проведе дитинство у байротівському таборі, напише згодом про цю дружбу так: «Як ми виїжджали з табору у різні напрями до Америки чи Канади, то прощалися i плакали більше, як за рідними, і відразу на нових поселеннях старалися нав'язати контакт між собою. Це було 70 років тому, а я ще донині утримую зв'язок із всіма моїми товаришками (особисто, листовно і телєфонічно)» ${ }^{74}$. Отже, вони підтримували зв'язок після переселення у постійні країни проживання, організовували спільні зустрічі, адже спільний досвід обєднував їх.

у таборах діяли позашкільні заклади, де діти могли займатися творчістю і проводити свій час поза таборовою кімнатою та вулицею. Зокрема, існували музичні, художні, балетні школи, театральні та танцювальні гуртки, хорові колективи, шахові клуби, де з дітьми працювали відомі українські громадські, культурні діячі та діячки. Так, музичну школу у Карлсфельді протягом 1945-1946 рр. очолював відомий піаніст, проф. Роман Савицький, у якій навчався 61 учень і викладало 12 педагогів ${ }^{75}$. Під керівництвом відомої балерина Валентини Переяславець у таборі Інгольштадт діяла дитяча школа балету ${ }^{76}$. У цьому ж таборі було організовано ляльковий театр, завданням якого було не лише розважати, а й виховувати маленьких українців (вистави «Червона Шапочка», «Пригоди Івасика Скитальця») $)^{77}$.

Важливе значення мало налагодження системи виховання та дозвілля, адже з утворенням таборів діти були представлені самі собі і багато часу проводили на вулиці. Василь Софронів-Левицький писав: «Наші діти живуть без опіки. В хаті не хочуть сидіти, бо власне своєї хати ніхто не має. Дві години в школі, а так надворі. Бігають до американців під шпиталь, де американці кидають їм через вікно куснички чоколяди, а потім, коли діти кинуться збирати, обливають їх згори водою» ${ }^{78}$. Система організованого дозвілля дозволяла зайняти та розвивати дітей, плекати українську ідентичність, оскільки в таборах проживали діти з різних регіонів, відірваних від рідної землі, українських традищій, мови.

У повоєнній Західній Німеччині та Австрії українці відновили Пласт. Організаційні одиниці Пласту (кіш, курінь) носили імена видатних українців (Євгена Коновальця, Лесі

\footnotetext{
${ }^{71}$ Богуславець Л. Судженого й конем не об'їдеш. Київ, 2016. С. 249.

${ }_{72}$ Залеська Онишкевич Л. Бомби, границі і два праві черевички. Друга світова війна очима дитини-біженця. Львів: Літопис, 2018. С. 156.

${ }^{73}$ Богуславець Л. Судженого й конем не об'їдеш. Київ, 2016. С. 247-252.

${ }^{74}$ Палідвор-Зєлик Л. Тисяча доріг - тисяча стежин. Спомини. Ню Йорк, 2020. С. 41.

${ }^{75}$ Винницький О. Історія табору Мюнхен-Карлсфельд в 1945-1946рр. // Міттенвальд 1946-1951 / Ред.ком. П. Рогатинський, О. Бучацький, О. Дужий та ін. Warren, Michigan, 2001. С. 11.

${ }^{76}$ Софронів Левищький В. Республіка за дротами (записки скитальця). Торонто: Видавництво «Новий шлях», 1983. C.118.

${ }^{77}$ Ibid. C. 47.

${ }^{78}$ Ibid. C. 15.
} 
Українки й ін.). Залежно від віку та статі члени Пласту належали до хлопчачих, дівчачих куренів і гнізд новачків (наймолодші члени). У Корнберзі 1946 р. пластунський кіш складався із близько 130 пластунів (два хлопчачих і один дівчачий курені, одне гніздо новаків) ${ }^{79}$. Члени відновленого у таборах Пласту так самі оцінювали його значення для них: «Після воєнних страхіть, серед тяжких буднів і турбот наших батьків про майбутнє, пластування давало нам можливість бути такими як інші молоді люди» ${ }^{80}$. Звичайно, що крім психологічної та соціальної ролі, Пласт відігравав важливу виховну, патріотичну функцію, плекав любов до України, ïï історії, культури, релігії. Незабутнє враження на дітей та юнацтво справляли прогулянки в лісі, в горах, полях, екскурсії, джемборі ${ }^{81}$, спортивні ігри. Пластуни часто мали зустрічі 3 відомими українщями, що проживали у таборах. Вони мали важливе виховне значення. Як відзначає у своїх споминах Л. Залеська Онишкевич: «легкий доступ до культурних діячів, культурних програм і публікацій, був головним впливовим чинником розвитку молодих людей» ${ }^{82}$. Юнацтво та молодь належали до Спілки української молоді (СУМ), яка також постала в повоєнній Німеччині. У таборі «Запоріжжя» (Окер, британська зона Німеччини) домівка СУМ була розмальована в українському стилі, оздоблена тризубом, прапорами і портретами героїв визвольних змагань ${ }^{83}$. СУМ мала метою плекання національної свідомості української молоді та ідей відновлення самостійності української держави фактично в умовах бездержавності та еміграції.

Національну свідомість плекало також родинне виховання. Батьки, що усвідомлювали можливість втрати в іноетнічному середовищі української ідентичності, намагалися виховувати дітей за українськими традиціями та стимулювати у дітей любов до власної культури, мови, книжки. Так, український письменник В. Софронів-Левицький, подарував своєму сину Ярку на Різдво кілька українських книжок, а на титульній сторінці «Історії України» батько написав:

«Куди б Тебе не повела

Щаслива чи лиха година

Ти завжди тям, не забувай

Що край твій рідний - Україна» ${ }^{84}$.

Звичайно, що у таборових умовах родинне виховання мало особливості, бо в таборовій кімнаті проживали чужі люди зі своїми звичками, висловлюваннями, поведінкою, яка не завжди відповідала потребам дітей. Адже існували такі негативні явища як картярство, пияцтво, паскування, сварки тощо. Заклики захищати дітей від таких впливів друкувалися на сторінках жіночої таборової преси, адже діти могли часто ставати свідками проблем дорослих і це відбивалося на їх поведінщі, уявленнях, вчинках чи словах.

Особлива роль у справі виховання дітей в еміграції відводилася українським жінкам. У 1947 р. ОУЖ видало листівку «Українці на чужині», в якій у 12 пунктах-заповідях було сфор-

\footnotetext{
79 Чужиною. 1946. Ч. 8. С. 27.

${ }^{80}$ Витанович-Галібей $P$. «Гей, життя ти наше, юне, молоде». Дещо про Пласт у Міттенвальді // Міттенвальд 1946-1951... C. 98.

81 Загальні збори пластунів. Перші повоєнні великі збори пластунів відбулися в Міттенвальді (Німеччина) 1947 р.

82 Залеська Онишкевич Л. Бомби, границі і два праві черевички... С. 157.

${ }^{83}$ Табір «Запоріжжя» Лідеман // Український скиталець. Одноднівка в таборі «Запоріжжя» в Окері (Гарц).

7 січня 1948 р. С. 4.

${ }^{84}$ Софронів Левищький В. Республіка за дротами (записки скитальця)... С. 47.
} 
мовано основні напрями діяльності жіноцтва в справі виховання своїх дітей, як свідомих і гідних українців ${ }^{85}$. Першим пунктом цих тез було усвідомлення того, що «Батьківщина - це Соборна, Самостійна, Незалежна Українська держава», а українська хата на чужині - це твердиня українства, в якій дитина пізнаватиме рідний край і навчиться його любити через українську пісню, казку, вишиванку, звичаї ${ }^{86}$. Отже, особлива роль в умовах втрати Батьківщини належала питанню збереження національної ідентичності дітей в умовах іноетнічного середовища. Американська дослідниця Т. Захра відзначає, що втрата ідентичності дітьми була однією 3 поширених соціальних проблем повоєнної Європи, що була переповнена біженцями ${ }^{87}$.

Саме в таборах деякі діти вперше у своєму житті відвідували церкву, театральні вистави, музичні та танцювальні вечори, читали книги не лише української, але й світової літератури, чи отримали перший досвід праці. Повоєнні реалії та життя в таборах для біженців у чужій країні змушували дітей досить швидко дорослішати. Старші діти за бажання могли працювати в таборі чи поза ним ${ }^{88}$, отримувати заробітну плату та мати право на додаткове харчування в їдальні як працююча особа ${ }^{89}$.

У споминах багатьох колишніх дітей-біженців перебування в таборах, попри всі побутові складнощі, представлено як щасливий період. Так, Л. Палідвор-Зєлик згадує «Життя в таборі ішло більш-менш нормально. Я ходила до гімназії, музичної школи, належала до Пласту, грала на фортепіяні, співала в хорі, брала участь у театральних виставах, їздила на прогульки, грала відбиванку, ходила на забави, на рандки [побачення - Aвт.] - одним словом мала "fun" [розваги - Aвm.] так, як правдивий "teenager" [підліток - Aвm.]. Ми не журилися так як наші батьки, про те якими будуть наші перспективи на будуче, що буде завтра, що будемо їсти, і не дуже дбали, що не мали вибагливого, модного одягу - ніхто не мав» ${ }^{90}$. Дітям здавалося, що життя поверталося до нормальних умов і вони це відчували, відвідуючи таборові садочки, школи, гімназії, святкуючи дні народження у маленьких таборових кімнатах, для когось навіть дозволяли завести котика, але це була лише ілюзія «нормальності». Відсутність дому, чужа країна, нестача їжі та одягу, непридатні для дітей житлові умови постійно нагадували, що це лише спроба побудувати «нормальне життя в ненормальних умовах». Частина страхів, що сформувалися у дитячій свідомості в роки війни та відразу після залишалася з ними все життя, що на рівні тих чи інший подальших життєвих подій проявлялися в кризові чи стресові моменти ${ }^{91}$.

Отже, чверть українських мешканців таборів для переміщених осіб і біженців у Західній Німеччині та Австрії становили діти. Попри різні обставини потрапляння до таборів, маючи різне соціальне походження їх дитинство проходило в умовах перших складних післявоєнних років, поза рідним домом, з характерними складнощами таборового повсякдення, які

\footnotetext{
${ }^{85}$ Архів НДЦ «Інститут досліджень української діаспори імені професора Любомира Винара» Національного університету «Острозька академія». Папка «Ляриса Музичка». Листівка «Українка на чужині». 1 арк.

${ }^{86}$ Ibid. 1 арк.

${ }^{87}$ Zahra T. Lost Children: Displacement, Family, and Nation in Postwar Europe... P. 45.

${ }^{88}$ Наприклад, старших дітей-біженців залучали до висадки дерев у лісах повоєнної Німеччини, за що ті отримували кошти. У випадку втрати одного з годувальників, ці працюючі діти могли відчутно матеріально підтримати родину.

89 Залеська Онишкевич Л. Бомби, границі і два праві черевички... С. 182-183.

${ }^{90}$ Палідвор-Зєлик Л. Тисяча доріг - тисяча стежин. Спомини. Ню Йорк, 2020. С. 35.

${ }^{91}$ Залеська Онишкевич Л. Бомби, границі і два праві черевички... С. 99.
} 
сильно впливали на фізичне та психологічне здоров’я дітей, їх навчання, виховання, самоідентифікацію. 3 однієї сторони, наявність українських садків, шкіл, Пласту, насичене культурне життя в таборах сприяло вихованню національно свідомої дітвори, сприяло їх відволіканню від наслідків війни, з іншої - діти чутливі до зміни звичного способу життя, до розриву зв'язків між членами родини, фізичного виснаження внаслідок недоїдання, переохолодження, хвороб. Спомини осіб, чиє дитинство пройшло в повоєнних таборах для біженців засвідчують, що цей досвід мав значний вплив на них та їх подальше життя. Варто сказати, що попри всі життєві складнощі та негаразди, непросте життя у таборах батьки намагалися виховувати своїх дітей на моральних, етичних і патріотичних засадах. Дитинство «нового покоління» українців у Ді-Пі таборах Західної Німеччини та Австрії визначалося не лише специфікою таборового життя та середовища, досвідом біженства, повоєнного часу та «чужої» країни, але й збереженням особливостей української культури і традицій у системі виховання.

\title{
Iryna Rybachok
}

\section{Ukrainian children in DP camps in Western Germany and Austria (the second half of the 1940s - early 1950s)}

\begin{abstract}
The paper aims to study the situation of Ukrainian refugee children in postwar Western Germany and Austria. In particular, the author highlights the issue of children's food, provision of clothing and school supplies, medical care, education, upbringing and leisure of Ukrainian children in refugee camps.

The approximate number of children of postwar Ukrainian emigration to Western Germany and Austria was 20\%. Some had an experience of being a refugee or Ostarbeiter children during World War II, while others were born in the first postwar years in Western Germany and Austria in Ukrainian immigrant families unwilling to return to Soviet Ukraine. Despite the different reasons of joining the camps and different social backgrounds, their childhood took place in the first difficult postwar years, outside their home, with the typical difficulties of camp life, which greatly affected the physical and psychological health of children, their education, upbringing, and self-identification. The daily life of Ukrainian refugee children was determined by the difficulties that were peculiar of all Ukrainian post-war emigration. They were associated primarily with insufficient provision of basic needs (lack of healthy and balanced food, lack of homes, unsatisfactory living and accommodation conditions), frequent relocations, separation from family, illnesses, etc. At the same time, it was in the camps that the physical and psychological rehabilitation of children from the war consequences began, the educational process continued, and children's leisure and upbringing peculiarities were organized.

Preservation and development of Ukrainian identity, language, national educational traditions, and the system of bringing up children outside Ukraine were the vital tasks for the Ukrainian community abroad, as it greatly contributed to the formation of national consciousness of Ukrainian children in exile. The shared childhood experience spent in the refugee camps united and grouped them in a foreign ethnic societies and promoted active participation in the public life of the Ukrainian diaspora in the later period of life.
\end{abstract}

Keywords: refugee children, the Ukrainians, DP camps, upbringing, leisure 